\title{
Effects of agriculture and seasonality on the soil hydrophysical properties of high-Andean dry páramo grasslands
}

\author{
Sebastián Patiño Gutiérrez ${ }^{1}$, Isabel Domínguez Rivera ${ }^{1}$, Martha Daza Torrez ${ }^{2}$, Edgar \\ Oviedo Ocaña ${ }^{1}$, Edwin Rowe ${ }^{3}$, and Boris Ochoa-Tocachi ${ }^{4}$ \\ ${ }^{1}$ Universidad Industrial de Santander \\ ${ }^{2}$ Universidad del Valle \\ ${ }^{3}$ Centre for Ecology \& Hydrology Bangor Site \\ ${ }^{4}$ ATUK Consultoría Estratégica
}

July 22, 2021

\begin{abstract}
One of the most essential ecosystem services provided by high-Andean páramos is streamflow buffering. A combination of soil, vegetation and climate characteristics provides páramos with an exceptional ability to store, regulate and supply water, particularly in their natural state. However, páramo catchments are seldom pristine. Agriculture is one of the most widespread human activities in páramos and considerably affects their soil hydrophysical properties. This research assesses how soil properties are affected by the conversion from natural páramo vegetation to fallow, onion, or potato crops. We measured Soil Organic Matter (SOM), Bulk density (Bd), pH and electric conductivity (EC) at three depths (0-5, 10-15 and 20-25 cm), in a stratified random survey of different land uses in the Eastern Cordillera of Colombia. Samples were collected in wet and dry seasons. Agricultural use affects all the studied properties, increasing $\mathrm{Bd}(+0.11 \mathrm{~g} \mathrm{~cm}-3)$, decreasing SOM $(-5.5 \%)$, and increasing $\mathrm{pH}(+1.3)$ and EC $(+187 \mu \mathrm{S} \mathrm{cm}-1)$. Seasonality did not have a significant effect on the studied properties under natural vegetation; however, there were significant differences between wet season and dry season in agricultural soils in SOM $(-7.2 \%$ and $+5.7 \%$ in fallow and potato crop, respectively) and $\mathrm{Bd}(-0.22 \mathrm{gr} \mathrm{cm}-3$ in crops). These changes show that agriculture in páramo grasslands leads to a significant decrease in soil porosity and water-holding capacity, which affects adversely the ecosystem hydrological regulation capacity. This paper contributes to a better understanding of the complexity of Andean páramos and provide crucial information to improve soil management, a key aspect for ensuring the sustainable provision of hydrological ecosystem services offered by Andean and other mountain ecosystems.
\end{abstract}

\section{INTRODUCTION}

Páramos are a collection of high-mountain ecosystems dominated by grasslands, wetlands and shrublands (Tovar, Arnillas, Cuesta, \& Buytaert, 2013). Usually, the characteristic saturated soils originate a variety of peatlands and lakes (J. C. Benavides, 2015). Páramos are located in the northern Andes in South America at elevations above the tree line (3,000-3,500 meters above sea level $-\mathrm{m}$ a.s.l.) and below the snow line (4,500-5,000 m a.s.l.) (Podwojewski, Poulenard, Zambrana, \& Hofstede, 2002). Their climate is cold with highly variable temperature and rainfall in both time and space (Buytaert et al., 2002; Ochoa-Tocachi et al., 2016). Páramo soils have a friable and crumbly consistency, an open structure (Buytaert, Deckers, \& Wyseure, 2006), and high organic matter content that generates a high porosity (Buytaert et al., 2002).

Overall, soil properties, natural vegetation and hydrological conditions equip páramos with a high capacity to store excess water during wet seasons and sustain flows during scarce dry seasons (Buytaert, Célleri, et al., 2006). This capacity to provide a seasonal buffer of water flows is known as hydrological regulation (Minaya, Corzo, Solomatine, \& Mynett, 2018) or streamflow buffering (Patiño et al., 2021). Streamflow 
buffering is considered a crucial hydrological ecosystem service provided by páramos (Buytaert \& Beven, 2011), contributing to water availability for over 100 million people in downstream Andean communities (Flores-López, Galaitsi, Escobar, \& Purkey, 2016).

On the other hand, páramos have traditionally been inhabited by communities of small farmers (estimated at around 10 million people) whose livelihoods are strongly dependent on the ecosystem biophysical characteristics (Hofstede, 2013). One of the main activities is agriculture, which replaces the native páramo vegetation with seasonal crops leading to changes on their soil hydrophysical properties including structure, porosity, organic matter content and water retention capacity, and thus altering hydrological processes (Avellaneda-Torres, León Sicard, \& Torres Rojas, 2018; Buytaert, Célleri, et al., 2006). For example, the generally saturated páramo soils are drained using trenches to allow drier conditions for cultivation (OchoaTocachi et al., 2016). Similarly, soil compaction and structure degradation by tillage and sun exposure reduce its water retention capacity and increase surface runoff (Poulenard, Podwojewski, Janeau, \& Collinet, 2001). Likewise, the removal of natural vegetation increases evapotranspiration and affects soil structure and porosity (Cárdenas-Agudelo, 2016) and produce hydrophobicity (Buytaert, Wyseure, De Bièvre, \& Deckers, 2005). Consequently, land use and management are key influencers of the hydrological cycle in páramos and of the hydrological ecosystem services that they provide (Buytaert et al., 2002).

Although páramos are regionally important, they are still understudied. Most research has been carried out in the humid páramos of southern Ecuador and western Colombia, whereas dry páramos have been neglected (Correa et al., 2020). In the last two decades, research has addressed the impacts of land use change on: i) the soil hydrophysical properties (Buytaert et al., 2002; Daza-Torres, Hernández, \& Triana, 2014; Poulenard, Podwojewski, \& Herbillon, 2003); ii) hydrological regulation (Buytaert et al., 2005; Poulenard et al., 2001); and iii) water provision (Buytaert, De Bièvre, Wyseure, \& Deckers, 2004; Ochoa-Tocachi et al., 2016). However, the spatial variability of climatic, hydrologic and soil conditions of these ecosystems yield equally variable results. This shows the complexity in the quantification of land use change impacts and the need to undertake specific studies that answer local questions and support local development (Ochoa-Tocachi et al., 2018), particular un sub-represented, understudied ecosystems such as the dry páramos or the Andean punas.

This study analyses the effect of changing natural páramo vegetation to agricultural crops (fallow, spring onion crops and potato crops) on soil hydrophysical properties associated to the hydrological service of streamflow buffering (i.e., soil organic matter, bulk density, $\mathrm{pH}$ and electric conductivity). Additionally, we studied the effect of rainfall pattern (i.e., wet season and dry season) over the studied hydrophysical properties. This research was carried out in a dry páramo study site (annual rainfall $<1,196 \mathrm{~mm}$ ) (Rangel, 2000), which is particular among páramos. Dry páramos cover only $6.0 \%$ and $1.4 \%$ of the páramo areas in Colombia and Ecuador, respectively (Hofstede, 2013), although larger areas of páramos are considered to resemble similar drier conditions than those of humid páramos. To the best of the authors' knowledge, research carried out in these particular conditions has been scarce. Thus, this paper contributes to an increased understanding of the complexity of Andean páramos and provide crucial information to improve land use management, a key aspect for ensuring the sustainable provision of hydrological services generated by these strategic ecosystems.

\section{MATERIALS AND METHODS}

This research was developed in three phases: i) selection of sampling units: data collection and analysis, and identification of main land uses; ii) collection and analysis of soil samples: sampling design, sample extraction and laboratory analysis; and iii) data analysis: descriptive statistics and statistical hypothesis testing.

\subsection{Study area}

We studied the Berlin dry páramo located in the Eastern Cordillera of Colombia at $07^{\circ} 06^{\prime} 15^{\prime} \mathrm{N}$ latitude and $72^{\circ} 56{ }^{\prime} 35^{\prime} \mathrm{W}$ longitude, inside the Santurbán páramo complex. This area is a strategic water source for 1,400 water-use rights, a hydropower generation central, and a centralized supply system that provides water to around 1 million people (C. Sarmiento \& Ungar, 2014). The study area is located in the Parra 
Juan Rodriguez village, spans between 3,420 and 3,630 $\mathrm{m}$ a.s.l., has an average annual temperature of $8^{\circ} \mathrm{C}$, a relative humidity of $86 \%$, an average annual rainfall of $702 \mathrm{~mm}$, and multiannual monthly rainfall between $40 \mathrm{~mm}$ and $702 \mathrm{~mm}$ during the dry and the wet seasons, respectively (Avellaneda, 2012).

Figure 1 shows the behavior of the multiannual monthly rainfall reported by the Berlin meteorological station $\left(07^{\circ} 11^{\prime} 24^{\prime \prime} \mathrm{N}\right.$ latitude and $72^{\circ} 52^{\prime} 12^{\prime \prime} \mathrm{W}$ longitude) for the period $1973-2018$, obtained from data provided by the Instituto de Hidrología, Meteorología y Estudios Ambientales (IDEAM, 2020).

\section{[Insert Figure 1]}

The soils in the study area are classified as Typic Dystropepts in the Inceptisols order, according to the United States Agricultural Department taxonomy (USDA \& NRCS, 2014), in association with a wavy steep slope. These soils are acidic, isomesic and udic. Morphologically, the soil profile has a distribution of horizons A-B-Cr: horizon A is dark brown, with a clay loam texture; horizon B is yellow with a texture similar to the upper horizon; horizon $\mathrm{Cr}$ is quartz monzonite. This is a well-drained, deep and strongly acidic soil, with low contents of calcium, magnesium and phosphorous, high in exchangeable aluminum and low in fertility (IGAC, 2003).

\subsection{Phase 1: Selection of sampling units}

The study area comprises two hydrological units draining to the Jordan river basin and was selected based on a review of cartographic information from secondary sources, field visits and stakeholder consultations, together with photointerpretation (Patiño, 2020). Two field visits with detailed walking surveys were carried out to identify the dominant land uses and to define sampling units (SUs). We selected SUs that were adjacent, had the same type of soils and similar climate, rainfall distribution, and topography to minimize confounding factors. This consideration allows to reduce uncertainty related to random crop locations in order to attribute observed changes on soil hydrophysical properties to land-use types.

Six SUs were identified, three under natural páramo vegetation and three under agricultural use. The SUs were named: páramo grasslands - low slope (Ls), páramo grasslands - steep slow (Ss), páramo - dense shrublands (Ds), agricultural use: fallow (F), spring onion crops (Oc), and potato crops (Pc). Fallow, in particular, is the consequence of a cultural practice in the area which consists of the removal of natural vegetation, mechanical ploughing at $30 \mathrm{~cm}$ depth, followed by a cycle of potato and barley cultivation, and then onion cultivation and livestock grazing. This practice has been performed during a period of approximately 30 years. This area is still grazed with an estimated animal density of 1.3 cows per hectare.

\subsection{Phase 2: Sample collection and analysis}

Ten monitoring campaigns were carried out, five in each season, dry and wet, over seven months (September 2019 - March 2020). A stratified discrete random sampling at different depths was implemented (0-5, 1015 and 20-25 cm). Samples and duplicates were randomly collected at each SU, resulting in ten points in each SU for different seasons. Thus, 60 samples were obtained in each SU, accounting for 360 collected soil specimens (180 in each season). Specimen extraction was performed using a hand-operated bucket auger and thin Kopecky rings of $100 \mathrm{~cm}^{3}$. Four soil hydrophysical properties were then analyzed: Soil Organic Matter (SOM), Bulk density (Bd), pH, and Electric Conductivity (Ec). Table 1 shows details regarding sampling and analytical methods.

\section{[Insert Table 1]}

Samples were transported in individual metallic rings with plastic lids in labeled airtight bags, preserved in a plastic cooler box protected from vibration using foam board layers, according to the recommendations from ASTM D4220-95 (ASTM, 2007). The analyses were carried out up to a maximum of two days after sample collection at the laboratory of the Grupo de Investigación en Recursos Hídricos y Saneamiento Ambiental at Universidad Industrial de Santander.

\subsection{Phase 3: Data analysis}


The assessment of differences on the soil hydrophysical properties was carried out at two levels: i) the influence of the rainfall regime (dry seasons and wet seasons) was established for each SU; and ii) the soil hydrophysical properties in the SUs under natural vegetation were compared with those in the SUs under anthropic land uses. Samples during each rainfall regime were classified according to the behavior of the multiannual monthly rainfall in the study area (Figure 1).

The soil hydrophysical properties for the two levels of analysis were assessed considering the three depths in which the soil specimens were extracted $(0-5,10-15$ and 20-25 cm) in order to avoid confounding effects of phenomena such as soil compaction, water content and organic matter distribution (EPA, 2014). In the two levels of analysis, data were assessed using descriptive statistics, completely randomized analysis of variance (ANOVA; normality test with Shapiro-Wilk method) and multiple comparisons (Fisher-LSD test). To analyze the influence of land use on the soil hydrophysical properties, boxplots were used to identify differences and data variability within the SU. All the statistical tests were carried out at a significance level of $5 \%$. In both levels of analysis, data were contrasted with current scientific literature on the influence of anthropic activities on the soils and hydrology of páramo ecosystems to evidence distinct patterns particular to those of dry páramos.

\section{RESULTS}

\subsection{Description and location of sampling units}

Figure 2 shows the study site and SUs locations where soil specimens were extracted. Six dominant land uses were identified in the study area: páramo grasslands - low slope (Ls), páramo grasslands - steep slope (Ss), páramo - dense shrublands (Ds); and agricultural use: fallow (F), spring onion crops (Oc), and potato crops (Pc). Table 2 summarizes the main characteristics of the dominant land uses studied.

[Insert Figure 2]

[Insert Table 2]

\subsection{Influence of seasonality on the soil hydrophysical properties of páramos}

Tables 3 and 4 show the influence of the rainfall regime on the soil hydrophysical properties in the SUs under natural vegetation and agricultural use, respectively. It is observed that natural vegetation did not show significant statistical differences on the soil properties between seasons, except for Bd in Ls for the three studied depths (Table 3). This low variability in the hydrophysical properties in the SUs under natural vegetation possibly occurs because natural vegetation protects the soil from the extreme climatic conditions of the páramo, such as high solar radiation, low temperature, strong winds, and high variation in daily temperature (Hedberg \& Hedberg, 1979). Likewise, natural vegetation has adapted to capture a large amount of water from rain, dew and mist, store water, minimize water losses by evapotranspiration (Salamanca, 1986), and to trap and accumulate organic matter in its structure (Josse et al., 2009). These two natural processes (water and organic matter storage) interact with each other to maintain regular soil hydrophysical properties despite seasonality changes, supporting their high capacity to store and sustain water fluxes.

[Insert Table 3]

[Insert Table 4]

On the other hand, in anthropic SUs, statistically significant differences were observed for SOM and Bd (Table 4). SOM showed statistically significant differences in F at surface level between seasons. An average maximum difference in SOM of $7.2 \%$ was observed in $\mathrm{F}$, in contrast with the $2.1 \%$ in Oc and $-3.2 \%$ in Pc $(p>0.05)$ when comparing average values for the wet and the dry season. The low variability in SOM observed in Oc could be associated to the frequent organic fertilization over this SU (every three months with unstable poultry manure), which does not occur in the other agricultural SUs.

Bd had statistically significant differences in Oc and Pc in the whole profile $(0-25 \mathrm{~cm})$, with smaller values in the dry season. Ploughing carried out in these plots could change soil structure, degrading macro and 
micro porosity, which can have different water saturation levels in the soil between seasons, influencing Bd values. In Oc and $\mathrm{Pc}$ an average difference of up to $0.21 \mathrm{~g} \mathrm{~cm}^{-3}$ can be associated to rainfall seasonality, similar to the results reported by Ordoñez, Galicia, Figueroa, Bravo, \& Peña (2015) who found differences of up to $0.14 \mathrm{~g} \mathrm{~cm}^{-3}$. F did not show statistically significant differences, possibly due to the high compaction (i.e., high Bd) in this SU.

$\mathrm{pH}$ and EC were not different between wet and dry seasons $(\mathrm{p}<0.05)$ in any of the SUs (Tables 3 and 5$)$. A slight reduction in these two properties was observed during the dry season, possibly because of the leaching of soluble ions (Juan et al., 2011) that can decrease pH and EC.

\subsection{Influence of agriculture on the soil hydrophysical properties of páramos}

This section describes the studied soil hydrophysical properties according to the SUs and depth (0-5, 10-15 and $20-25 \mathrm{~cm})$. Furthermore, the changes on the hydrophysical properties associated to the agricultural land uses (F, Oc, Pc) are analyzed and compared with natural vegetation covers (Ls, Ss, Ds).

\subsubsection{Soil Organic Matter (SOM)}

Figure 3 shows SOM results in the six SUs for the three studied depths. A decrease in SOM with depth is observed for the natural vegetation soils, while SOM was relatively constant with depth in soils under anthropic land use. This is corroborated with the average difference in SOM between $0-5 \mathrm{~cm}$ and $0-25 \mathrm{~cm}$, with values of $12.4 \%$ for natural vegetation and smaller values for $\mathrm{F}(3.9 \%)$, Oc $(0.7 \%)$ and $\mathrm{Pc}(0.8 \%)$. The SOM gradient in natural vegetation could be related with a higher fraction on biomass in the superficial soil layers, and the limitation of microbial activity with depth caused by scarce oxygen, temperature, and nutrients (Dungait, Hopkins, Gregory, \& Whitmore, 2012). In contrast, in anthropic uses, the incorporation of fresh organic matter from external sources together with ploughing can homogenize organic matter in the ploughed soil profile.

[Insert Figure 3]

Natural vegetation SUs had average SOM values of $25.0 \%$ at the surface and up to $52.3 \%$ in riparian areas (Ds). These values agree with reports from natural vegetation in other dry páramos of 23.0-39.0\% (PeñaQuemba, Rubiano-Sanabria, \& Riveros-Iregui, 2016). In contrast, in humid páramo, SOM values up to $42.6 \%$ have been reported (Agudelo-Cárdenas, 2016). The generally high SOM values observed in páramos are possibly a consequence of a positive feedback between SOM and WC (Buytaert, Célleri, De Bièvre, \& Iñiguez, 2007). Podwojewski et al. (2002) ascribe the high SOM in natural vegetation to three factors: i) fresh organic matter originating from plant decomposition, ii) cold conditions and microbial inhibition, and iii) protection from mineralization by organometallic complexes.

With regards to agricultural land uses, F had the lowest SOM values among the SUs ( $\sim 15.8 \%)$. According to Hofstede (1995), appreciable changes in the soils because of livestock grazing are evident at cattle densities over 10 units per hectare. However, in our study area, the livestock density was less than 2 units per hectare. The observed low SOM levels could be more related to soil depletion during its productive stage followed by a low recovery, which is typical of páramo soils (Avellaneda-Torres et al., 2018).

\subsubsection{Bulk density $(\mathrm{Bd})$}

Figure 4 shows Bd results in the six SUs for the three analyzed depths. In natural vegetation SUs, Bd increased with depth, which is consistent with results from Alvarado and Forsythe (2005). An average increase of 0.11 $\mathrm{g} \mathrm{cm}^{-3}$ is from the $0-5 \mathrm{~cm}$ level to the $20-25 \mathrm{~cm}$ level. In contrast, in agricultural uses, Bd was approximately constant in the studied profile. The higher variation of Bd between natural and agricultural uses was at the surface in $\mathrm{F}\left(0.16 \mathrm{~g} \mathrm{~cm}^{-3}\right)$ and followed by crops $\left(<0.05 \mathrm{~g} \mathrm{~cm}^{-3}\right)$. Pore size redistribution and its temporary increase as result of ploughing (I. Benavides et al., 2018) could cause the observed Bd pattern in agricultural SUs.

[Insert Figure 4] 
At the surface, four statistically significant different groups in Bd were observed: the first with natural grasslands (Ls and Ss; $\left.0.89 \mathrm{~g} \mathrm{~cm}^{-3}\right)$, the second for Ds $\left(0.78 \mathrm{~g} \mathrm{~cm}^{-3}\right)$, the third for F $\left(1.02 \mathrm{~g} \mathrm{~cm}^{-3}\right)$, and the fourth for crops ( $\mathrm{Oc}$ and $\mathrm{Pc} ; 0.84 \mathrm{~g} \mathrm{~cm}^{-3}$ ). The differences between these groups result from the vegetation characteristics (plant root density associated with porosity) (Aggarwal, Choudhary, Singh, \& Chakraborty, 2006) and soil management, which directly influence Bd. At 20-25 cm depth, two statistically dissimilar groups appeared: the first with Ls, Ss, Ds and F; and the second with crops. The linkage in the uses for the first group is soil genesis at this depth $(<20 \mathrm{~cm})$, and for the second group is the distance of ploughing from the surface $(30 \mathrm{~cm})$.

The natural vegetation had a Bd in the assessed profile between 0.86 and $1.09 \mathrm{~g} \mathrm{~cm}^{-3}$, in agreement with other values reported for dry páramo natural vegetation (Buytaert et al., 2005) and with those observed by Farley, Kelly, and Hofstede (2004) $\left(1.17 \mathrm{~g} \mathrm{~cm}^{-3}\right)$ whose annual rainfall $(1,130 \mathrm{~mm})$ was much higher than that of the present research. $\mathrm{F}$ had critical Bd values, with an increase of up to $19.5 \%$ compared to natural vegetation (values between 1.03 and $1.17 \mathrm{~g} \mathrm{~cm}^{-3}$ ), consistent with other studies (Daza-Torres et al., 2014). Likewise, the results are in agreement with Estupiñán, Gómez, Barrantes, and Limas (2009), who found an increase in Bd of up to $35.0 \%$ in fallow SUs compared to natural vegetation Sus. Podwojewski et al. (2002) found that overgrazing can increase Bd up to $0.80 \mathrm{~g} \mathrm{~cm}^{-3}$.

Bd conditions in this study were related to soil management. In cropped areas, ploughing initially favors soil conditions to increase crop productivity, by boosting aeration and nutrient availability, breaking the natural soil structure and reducing Bd (Strudley, Green, \& Ascough Ii, 2008). However, the rapid oxidation of SOM (without physical protection) and the low concentration of interchangeable bases force to deep ploughing (Hofstede, 2001), which in the long term can provoke an undesirable effect: soil depletion and Bd increase (Daza-Torres et al., 2014; Podwojewski et al., 2002). This phenomenon, however, was not yet evident in Oc and Pc in the study area, due to the recent transformation of natural vegetation to these uses. On the other hand, F had more critical conditions because of soil abandonment, possibly due to the previously explained cultural practice in the area. Results found for Bd are similar to those from Quichimbo et al. (2012) comparing natural vegetation and fallow.

\section{$3.3 .3 \mathrm{pH}$}

Figure 5 shows $\mathrm{pH}$ results in the six SUs for the three depths assessed. Natural vegetation had a lower $\mathrm{pH}$ at the surface that slightly increased with depth, with a variation of 0.3 units between 0 and $25 \mathrm{~cm}$. This pattern in $\mathrm{pH}$ could be related to three factors that lead to the transformation of interchangeable bases at the soil surface: rainfall (leachate of bases), SOM (formation of soluble bicarbonates dragged in depth, generating the elimination of bases), microbial activity (mineralization of organic matter by transforming $\mathrm{N}$ from ammonia, nitrites and nitrates) and parent material (Cárdenas-Fonseca, 2015). In agricultural SUs, pH was approximately constant in the profile, possibly because of the turning of the soil which homogenizes its characteristics.

\section{[Insert Figure 5]}

The natural vegetation had the most acidic soil in the study area (4.6), being lower for Ds, with 3.9 at the surface level. The low $\mathrm{pH}$ in Ds could be associated to the accumulation of weak organic acids (fulvic and humic) in the degradation process of fresh organic matter (Martínez, Fuentes, \& Acevedo, 2008). In general, páramo soils are characterized for being acidic due to the high concentration of aluminum (Estupiñán et al., 2009) and organic acids (carboxyls and phenolics) (Jaramillo, 2002; Martínez et al., 2008).

pH in agricultural SUs was low, associated to the application of amendments (Estupiñán et al., 2009), such as agricultural lime to increase productivity and to the retention and cation exchange (Hernández, Triana, \& Daza-Torres, 2009) in addition to nutrient assimilation. The plot under Oc had a high variability in $\mathrm{pH}$, possibly associated to a heterogeneous application of fertilizers and amendments. This variability was not observed in Pc, probably because of its recent transformation from natural vegetation to crops and lower use of agrochemicals as reported by the farmers. Our results for F and Pc are similar to those from Daza-Torres et al. (2014) in another páramo complex (Sumapaz). 


\subsubsection{Electric conductivity (EC)}

Figure 6 shows EC results in the six SUs for the three assessed depths. In general, the soil in the study area had an EC of $<2 \mu \mathrm{S} \mathrm{cm}{ }^{-1}$, classified as a non-saline soil (Hoorn \& Alphen, 1994). The natural vegetation, Ls and Ss had the lowest EC $(108 \mu \mathrm{S} / \mathrm{cm})$ compared to other SUs, whereas EC for Ds was slightly higher $\left(185 \mu \mathrm{S} \mathrm{cm}^{-1}\right)$. The agricultural crops had the highest $\mathrm{EC}$ with average values of 321 and $231 \mu \mathrm{S} \mathrm{cm} \mathrm{cm}^{-1}$ for Oc and Pc, respectively. Fertilization could increase the concentration of salts in the soil (Cortés, Pérez, \& Camacho-Tamayo, 2013) and consequently EC.

[Insert Figure 6]

\section{DISCUSSION}

\subsection{Influence of seasonality on the soil hydrophysical properties of páramos}

The hydrophysical properties of soils under natural vegetation showed gradients according to depth (except for Ds in the wet season). In soils under agricultural use, none of the properties showed an evident pattern or gradient related to depth. This shows that human practices, such as ploughing and fertilization, change soil structure and properties, which affects the natural hydrophysical occurrence (reduction of SOM and EC with depth, and increase in $\mathrm{Bd}$ and $\mathrm{pH}$ with depth). This trend was different only in the area of Ds, in which the $\mathrm{pH}$ increased with depth, probably for being an area where fresh organic matter accumulates and promotes an increase in weak organic acids in the surface.

In general, the soil hydrophysical properties under natural vegetation did not exhibit statistically significant differences in relation to the rainfall regime. The exception was $\mathrm{Bd}$, in the area of páramo grasslands with low slope (Ls) (average reduction in the three depths of $14.4 \%$ from the wet season to the dry season). This difference of $\mathrm{Bd}$ in Ls is counterintuitive with results from SOM in this area but can be associated to the fact that this plot is located on top of a páramo valley (3620-3660 m a.s.l.) with higher exposition to solar radiation, winds and predominantly covered with low-size vegetation. The stability of the soil hydrophysical properties despite the rainfall regime in the other natural areas could be associated to the vegetation type. Plant characteristics allow them capture water using different mechanisms and limit evapotranspiration (Salamanca, 1986), while accumulating organic matter and improving soil structure (Josse et al., 2009). This result in high organic matter content, contributing to the preservation of soil properties independently of seasonality (i.e., sustaining hydrological regulation).

In contrast with natural vegetation, some hydrophysical properties in soils under agricultural use showed changes in relation to the rainfall regime. Comparing the wet and the dry season, F reduced SOM in about $38.7 \%(0-5 \mathrm{~cm})$, possibly because of its land use history exhausting soil conditions (Sandoval, 2004). In soils under agriculture subject to ploughing, the micro-aggregates of the soil, where the organic matter is mainly present (Six, Frey, Thiet, \& Batten, 2006), are broken and they are also exposed to the climate conditions of the páramo, which favors the mineralization or loss of organic matter (Balesdent, Chenu, \& Balabane, 2000). Furthermore, the increase in runoff and erosion during the wet season can favor the lixiviation of soil organic carbon as observed in Oc (Otero, Figueroa, Muñoz, \& Peña, 2011).

In cropped plots, Bd showed changes according to the season, in all the assessed depths, $19.8 \%$ in in Oc, and $25.4 \%$ in Pc. These changes in Bd are associated to soil structure alteration that can generate a loss in the streamflow buffering capacity of páramo catchments (Avellaneda-Torres et al., 2018; Dorel, Roger-Estrade, Manichon, \& Delvaux, 2000).

The results obtained here indicate that agricultural management increases the sensitivity of the soil hydrophysical properties to seasonal fluctuations (rainfall regime) in cropped areas (Hofstede, 1995; Ordoñez et al., 2015). The high stability of the soil properties under natural vegetation, especially SOM, could explain the low inter-seasonal variability observed.

\subsection{Influence of agriculture on the soil hydrophysical properties of páramos}


The soil hydrophysical properties in the natural vegetation SUs did not show significant changes according to depth. On the other hand, comparing the effect of land use transformation (natural to agricultural) on the soil hydrophysical properties, the following conditions emerged:

The changes in SOM, comparing agricultural areas with natural vegetation areas, were higher at the surface level. In this case, $\mathrm{F}$ had a higher reduction in the median values (40.0\% compared to Ls and Ss), followed by Pc (31.1\% compared to Ls and Ss) and Oc (27.3\% compared to Ls and Ss). The increase in the decomposition rate (Henry, Mabit, Jaramillo, Cartagena, \& Lynch, 2013), the rapid oxidation in unprotected areas (Poulenard et al., 2003), and the mineralization of organic waste (Sainju, Whitehead, \& Singh, 2003) can reduce $\mathrm{SOM}$, as observed in the cultivated areas in this study. In addition, the agricultural practices, in which organic amendments and biomass inputs are not considered, prevent the preservation or restoration of the natural soil conditions, leading to a slow passive recovery (Harden, 2006). The transformation of páramos to agricultural lands changes the biological soil dynamics (Avellaneda-Torres et al., 2018), resulting in a high enzymatic activity ( $\mathrm{Li}$ et al., 2018), favorable for crops but at the cost of losing soil stability and the native microbiological diversity. These properties directly influence soil carbon storage (Coonan et al., 2020) and the biotransformation process of organic matter and nutrients. The use of compost (Melero, Madejón, Ruiz, \& Herencia, 2007) and zero tillage (López-Bellido, Fontán, López-Bellido, \& López-Bellido, 2010; Sainju et al., 2003) increase enzymatic activity and surface organic carbon, without an important alteration of soil structure, restoring soil aggregation and preventing erosion. This yields better results than traditional agricultural practices (e.g., the addition of unstable organic matter to the soil) (Melero et al., 2011).

The greatest average changes in $\mathrm{Bd}$, comparing agricultural land uses and natural vegetation were observed at higher depths. The most significant change occurred in Pc, where Bd was approximately homogenous at all depths and decreased compared to natural vegetation (Ls and Ss) on $25.9 \%$. In Oc, a reduction of $19.6 \%$ of Bd (compared to Ls and Ss) occurred at the same depth. F had the higher increase in Bd at the surface (0-5 cm; $19.8 \%$ compared to natural vegetation). In the study area, the soils under Oc and Pc were recently transformed, for which, the observed changes in Bd were relatively small. In contrast, F, an abandoned area after an intense period of agricultural and livestock use, had the worst hydrological conditions compared to all the studied land uses.

$\mathrm{pH}$ was acidic in areas under natural vegetation as has been found in other páramo studies (Daza-Torres et al., 2014; Estupiñán et al., 2009). In contrast, in the agricultural areas, pH was more neutral, probably as result of the application of amendments (e.g., agricultural lime) and fertilizers. In this case, the greater changes in the $\mathrm{pH}$ of agricultural areas were observed close to the surface, being higher in Oc (an increase in average values of $31.1 \%$ compared to Ls and Ss) because of an intensive use and diversity of agricultural inputs. In contrast to Oc, the change was $11.1 \%$ in Pc at the surface level compared to Ls and Ss.

In relation to EC, Oc and Pc had the greatest changes in the deep layer (average increase in 323.9\% and $201.4 \%$, respectively compared to Ls and Ss). This can be associated to an inefficacy of managerial practices, for example, an unequal application of amendments and fertilizers and excessive use of agrochemicals (Wei et al., 2009). In F, the change occurred at the surface level, but it was subtler compared to other anthropic uses (13\% increase compared to Ls and Ss), which could suggest signs of recovery in this degraded soil.

Ds generally behaved similar to other natural vegetation covers (Ls and Ss) in the hydrophysical properties of SOM and Bd. However, $\mathrm{pH}$ and EC had a dissimilar behavior, showing a lower $\mathrm{pH}$ (0.5 units in average compared to Ls and Ss), and higher EC (in average $71.3 \%$ over Ls and Ss). This suggests that Ds had higher ability to store water and nutrients (Martinez, Vanderlinden, Ordóñez, \& Muriel, 2009), together with soil aggregation with continuous macropores which favor the conduction of electric current (Lal, 1997).

\subsection{Implications on hydrological ecosystem services}

Páramo soils have a fundamental role on the hydrological cycle and the provision of ecosystem services in Andean communities (WWF, 2006), particularly for streamflow buffering (Patiño et al., 2021) . However, agricultural activities impair soil properties that sustain these services (Avellaneda-Torres et al., 2018; Dorel et al., 2000). 
The present study confirms the implications of land use change on the hydrophysical properties of páramo soils for the understudied dry páramo. Agricultural activities in páramo areas affect the pore distribution in the soil (Daza-Torres et al., 2014), significantly reducing macroporosity and increasing water infiltration velocity, runoff and erosion (Hernández et al., 2009). Likewise, these activities reduce macroporosity which could favor the breakage of aggregates and increase the dispersion of clays (Jaramillo, 2002), blocking pores and limiting water retention capacity (Dorel et al., 2000). This has been evidenced by several authors that report a higher decline in the soil water retention capacity at high suctions, linked with the permanent wilting point and soil microporosity (Agudelo-Cárdenas, 2016; Camargo-García, Dossman, Rodríguez, Arias, \& Galvis-Quintero, 2012; Daza-Torres et al., 2014; Farley et al., 2004; Quichimbo et al., 2012).

The removal of natural vegetation and the direct exposure of the soil to the environmental high-Andean conditions oxidize the SOM, which together with the scant input of biomass from crops, is insufficient to restore the natural soil conditions (Daza-Torres et al., 2014). The frequent cycle of turning, drying and cultivation leads to an overexploitation of the soils, ending in decline and abandonment. Although burning, a practice commonly associated with agriculture and grazing, increase the available SOM, without protection, the organic matter is rapidly oxidized and released to the atmosphere in the form of $\mathrm{CO}_{2}$, resulting in a progressive loss of SOM (Peña-Quemba et al., 2016). In the short-term, agricultural practices might seem to produce positive changes on soil properties that are useful to increase crop yields; however, in the long-term, these practices deteriorate soil hydrophysical properties (Strudley et al., 2008) and thus their hydrological regulation capacity (Patiño et al., 2021).

Agricultural activities, such as ploughing, reduce soil roughness and create artificial drainages that accelerate runoff and disrupt water storage, leading to an increase in peak flows (Buytaert, Célleri, et al., 2006). This could result in a high impact on water management in the Andean region due to the loss of dry-season base flow in surface sources originating in the páramo highlands (Buytaert et al., 2002). As result of agricultural activities, a variety of impacts have been identified: i) an increase in the ratio between peak flow and base flow (6.9) (Buytaert et al., 2004; Ochoa-Tocachi et al., 2016); ii) a reduction of the hydrological regulation capacity of up to $40 \%$, using the linear reservoir concept (Buytaert et al., 2005); (iii) and an increase on surface runoff of up to $300 \%$ (Poulenard et al., 2001). However, other studies have found a modest increase on surface runoff (e.g., 2\%, (L. Sarmiento, 2000), or a lack of statistically significant differences in soil infiltration capacity caused by the transformation of natural vegetation to crops (Hofstede, 1995). This shows the complexity of the phenomenon of land use change in páramos and the need to undertake further research in this topic (Ochoa-Tocachi et al., 2018).

New conservation practices, such as waste reuse or zero tillage in agricultural areas aiming at decreasing soil depletion (Giller et al., 2015) have been proposed to improve soil structure and reduce erosion. This is expected to maintain the soil water retention capacity (Kirkegaard et al., 2014) compared to traditional agricultural practices. These alternative practices could have a potential in páramo ecosystems, where the conflict between conservation and people's livelihoods who have traditionally inhabited these areas is present.

\section{CONCLUSIONS}

Agricultural practices change the hydrophysical properties of páramo soils that are associated to the hydrological service of streamflow buffering. The information shown in this paper represents an understudied ecosystem, dry páramos, that differs from the more studied humid páramos. It shows that changing natural vegetation to potato crops, onion crops and later, livestock, leads to a reduction in soil organic matter and water content and an increase in bulk density, especially at the surface level. This trend was evidenced by the decline of these variables in the areas transformed to fallow soil. Furthermore, páramo soils under anthropic uses showed higher variability in these hydrophysical properties with rainfall seasonality.

Activities such as ploughing, agrochemical use and irrigation influenced the hydrophysical properties of the páramo soils under onion crops, where the gradient on the hydrophysical properties according to depth typical of natural areas- disappeared. In addition, substantial changes in $\mathrm{pH}$ and electric conductivity were observed. Even if irrigation contributes to preserve water content, and frequent fertilization provides organic 
matter, the organic matter content decreases in the long-term with extended cultivation. Furthermore, as the soil hydrophysical properties are severely compromised, this leads to the abandonment of these lands and their conversion to fallow.

The increase in bulk density, electric conductivity and the reduction in organic matter could impair the ability of páramo catchments for streamflow buffering. This will increase surface runoff and reduce base flow, which worsens the capacity of páramo catchments to maintain steady flows and allow multiple water uses. It is extremely important to develop strategies that can communicate this information to decision-making institutions and farmers aiming at a collaborative search of best practices that provide opportunities to harmonize people's livelihoods with environmental conservation of páramos and of the ecosystem services dependent on them.

\section{ACKNOWLEDGEMENTS}

This study was funded by Universidad Industrial de Santander through the Santander Científico Research Program (2018), Grant number 2438. B.O.T. and E.R. acknowledge funding from UKRI under the PARAGUAS Project (grant NE/R017654/1). B.O.T. also acknowledges the National Secretariat for Higher Education, Science, Technology and Innovation of Ecuador (SENESCYT).

\section{DATA AVAILABILITY}

The data that support the findings of this study are available from the corresponding author upon reasonable request.

\section{REFERENCES}

Aggarwal, P., Choudhary, K. K., Singh, A. K., \& Chakraborty, D. (2006). Variation in soil strength and rooting characteristics of wheat in relation to soil management. Geoderma, 136 (1-2), 353-363. doi:10.1016/j.geoderma.2006.04.004

Agudelo-Cárdenas, M. F. (2016). Ecohydrology of paramos in Colombia: Vulnerability to climate change and land use. (Doctora en Ingeniería - Recursos Hidráulicos PhD), Universidad Nacional de Colombia, Medellín, Colombia.

Alvarado, A., \& Forsythe, W. (2005). Variación de la densidad aparente en órdenes de suelos de Costa Rica. Agronomía costarricense: Revista de ciencias agrícolas, 29 (1), 85-94.

ASTM. (2001). Standard test method for pH of soils Annual Book of ASTM Standards (Vol. ASTM D4972 - 01, pp. 1-7). West Conshohocken, PA: American Society for Testing and Materials (ASTM).

ASTM. (2007). Standard Practices for Preserving and Transporting Soil Samples Annual Book of ASTM Standards (Vol. ASTM D4220 - 95, pp. 1-11). West Conshohocken, PA: American Society for Testing and Materials.

ASTM. (2011). Standard Test Methods for Organic Matter Content of Athletic Field Rootzone Mixes Annual Book of ASTM Standards (Vol. Annual Book of ASTM Standards, pp. 1-7). West Conshohocken, PA: American Society for Testing and Materials (ASTM).

ASTM. (2014). Standard Test Methods for Specific Gravity of Soil Solids by Water Pycnometer Annual Book of ASTM Standards (Vol. ASTM D854-14, pp. 1-8). West Conshohocken, PA: American Society for Testing and Materials (ASTM).

Avellaneda-Torres, L. M., León Sicard, T. E., \& Torres Rojas, E. (2018). Impact of potato cultivation and cattle farming on physicochemical parameters and enzymatic activities of Neotropical high Andean Páramo ecosystem soils. Science of the Total Environment, 631-632 , 1600-1610. doi:10.1016/j.scitotenv.2018.03.137

Avellaneda, M. (2012). Componente Biótico. In I. López (Ed.), Estudio Páramo de Santurbán . Bucaramanga: Corporación Autónoma Regional para la Defensa de la Meseta de Bucaramanga (CDMB). 
Balesdent, J., Chenu, C., \& Balabane, M. (2000). Relationship of soil organic matter dynamics to physical protection and tillage. Soil and Tillage Research, 53 (3-4), 215-230. doi:10.1016/S0167-1987(99)00107-5

Benavides, I., Solarte, M., Pabón, V., Ordoñez, A., Beltrán, E., Rosero, S., \& Torres, C. (2018). The variation of infiltration rates and physical-chemical soil properties across a land cover and land use gradient in a Paramo of southwestern Colombia. Journal of Soil and Water Conservation, 73 (4), 400-410. doi:10.2489/jswc.73.4.400

Benavides, J. C. (2015). The effect of drainage on organic matter accumulation and plant communities of high-altitude peatlands in the Colombian tropical Andes. Mires and Peat, 15 , 1-15.

Buytaert, W., \& Beven, K. (2011). Models as multiple working hypotheses: Hydrological simulation of tropical alpine wetlands. Hydrological Processes, 25 (11), 1784-1799. doi:10.1002/hyp.7936

Buytaert, W., Célleri, R., De Bièvre, B., Cisneros, F., Wyseure, G., Deckers, J., \& Hofstede, R. (2006). Human impact on the hydrology of the Andean páramos. Earth-Science Reviews, 79 (1-2), 53-72. doi:10.1016/j.earscirev.2006.06.002

Buytaert, W., Célleri, R., De Bièvre, B., \& Iñiguez, V. (2007). The impact of pine plantations on water yield: A case study from the ecuadorian andes. Paper presented at the Proceedings in Third International Symposium on Integrated Water Resources Management, Bochum, Germany.

Buytaert, W., De Bièvre, B., Wyseure, G., \& Deckers, J. (2004). The use of the linear reservoir concept to quantity the impact of changes in land use on the hydrology of catchments in the Andes. Hydrology and Earth System Sciences, 8 (1), 108-114.

Buytaert, W., Deckers, J., Dercon, G., De Bièvre, B., Poesen, J., \& Govers, G. (2002). Impact of land use changes on the hydrological properties of volcanic ash soils in South Ecuador. Soil Use and Management, 18 (2), 94-100. doi:10.1111/j.1475-2743.2002.tb00226.x

Buytaert, W., Deckers, J., \& Wyseure, G. (2006). Description and classification of nonallophanic Andosols in south Ecuadorian alpine grasslands (páramo). Geomorphology, 73 (3-4), 207-221. doi:10.1016/j.geomorph.2005.06.012

Buytaert, W., Wyseure, G., De Bièvre, B., \& Deckers, J. (2005). The effect of land-use changes on the hydrological behaviour of Histic Andosols in south Ecuador. Hydrological Processes, 19 (20), 3985-3997. doi:10.1002/hyp.5867

Camargo-García, J. C., Dossman, M. Á., Rodríguez, J. A., Arias, L. M., \& Galvis-Quintero, J. H. (2012). Soil changes after a fire event in a paramo ecosystem: Los nevados natural national Park, Colombia.Acta Agronomica, 61 (2), 151-165.

Cárdenas-Agudelo, M. F. (2016). Ecohydrology of paramos in Colombia: vulnerability to climate change and land use. (Doctora en Ingeniería - Recursos Hidráulicos PhD), Universidad Nacional de Colombia, Medellín (Colombia).

Cárdenas-Fonseca, M. (2015). Evaluación de la calidad de los suelos de páramo intervenidos y no intervenidos en la comuna Monjas Bajo, Parroquia Juan Montalvo, Cantón Cayambe. (Ingeniería en biotecnología de los recursos naturales), Universidad Politécnica Saleciana, Quito.

Coonan, E. C., Kirkby, C. A., Kirkegaard, J. A., Amidy, M. R., Strong, C. L., \& Richardson, A. E. (2020). Microorganisms and nutrient stoichiometry as mediators of soil organic matter dynamics. Nutrient Cycling in Agroecosystems, 117 (3), 273-298. doi:10.1007/s10705-020-10076-8

Correa, A., Ochoa-Tocachi, B. F., Birkel, C., Ochoa-Sánchez, A., Zogheib, C., Tovar, C., \& Buytaert, W. (2020). A concerted research effort to advance the hydrological understanding of tropical páramos.Hydrological Processes, 34 (24), 4609-4627. doi:10.1002/hyp.13904 
Cortés, D., Pérez, J., \& Camacho-Tamayo, J. (2013). Relación espacial entre la conductividad eléctrica y algunas propiedades químicas del suelo. Revista UDCA : Actualidad Ė divulgación Científica, 16 (2), 401-408. doi:10.31910/rudca.v16.n2.2013.912

Daza-Torres, M., Hernández, F., \& Triana, F. (2014). Efecto del uso del suelo en la capacidad de almacenamiento hídrico en el páramo de Sumapaz-Colombia. Revista Facultad Nacional de Agronomía Medellín, 67 (1), 7189-7200. doi:10.15446/rfnam.v67n1.42642

Dorel, M., Roger-Estrade, J., Manichon, H., \& Delvaux, B. (2000). Porosity and soil water properties of Caribbean volcanic ash soils. Soil Use and Management, 16 (2), 133-140. doi:10.1111/j.1475-2743.2000.tb00188.x

Dungait, J. A. J., Hopkins, D. W., Gregory, A. S., \& Whitmore, A. P. (2012). Soil organic matter turnover is governed by accessibility not recalcitrance. Global Change Biology, 18 (6), 1781-1796. doi:10.1111/j.13652486.2012.02665.x

EPA. (2014). Operating Procedure: Soil Sampling (Vol. LSASDPROC-300-R4, pp. 24). Washington, DC: Environmental Protection Agency (EPA).

Estupiñán, L., Gómez, J., Barrantes, V., \& Limas, L. (2009). Efecto de actividades agropecuarias en las características del suelo en el páramo El Granizo,(Cundinamarca-Colombia). Revista UDCA : Actualidad $\mathscr{E}$ divulgación Científica, 12 (2), 79-89. doi:10.31910/rudca.v12.n2.2009.694

Farley, K. A., Kelly, E. F., \& Hofstede, R. G. M. (2004). Soil organic carbon and water retention after conversion of grasslands to pine plantations in the Ecuadorian Andes. Ecosystems, 7 (7), 729-739. doi:10.1007/s10021004-0047-5

Flores-López, F., Galaitsi, S. E., Escobar, M., \& Purkey, D. (2016). Modeling of Andean páramo ecosystems' hydrological response to environmental change. Water (Switzerland), 8 (3), 94. doi:10.3390/w8030094

Giller, K. E., Andersson, J. A., Corbeels, M., Kirkegaard, J., Mortensen, D., Erenstein, O., \& Vanlauwe, B. (2015). Beyond conservation agriculture. Frontiers in Plant Science, 6 (OCTOBER). doi:10.3389/fpls.2015.00870

Harden, C. P. (2006). Human impacts on headwater fluvial systems in the northern and central Andes. Geomorphology, 79 (3-4), 249-263. doi:10.1016/j.geomorph.2006.06.021

Hedberg, I., \& Hedberg, O. (1979). Tropical-alpine life-forms of vascular plants. Oikos, 33 (2), 297-307. doi: $10.2307 / 3544006$

Henry, A., Mabit, L., Jaramillo, R. E., Cartagena, Y., \& Lynch, J. P. (2013). Land use effects on erosion and carbon storage of the Río Chimbo watershed, Ecuador. Plant and Soil, 367 (1-2), 477-491. doi:10.1007/s11104-012-1478-y

Hernández, F., Triana, F., \& Daza-Torres, M. (2009). Efecto de actividades agropecuarias en la capacidad de infiltración de los suelos del páramo del Sumapaz. Ingeniería de Recursos Naturales y del Ambiente (8), 29-38.

Hofstede, R. (1995). Effects of livestock farming and recommendations for management and conservation of páramo grasslands (Colombia).Land Degradation $\&$ Development, 6 (3), 133-147. doi:10.1002/ldr.3400060302

Hofstede, R. (2001). El impacto de las actividades humanas sobre el páramo. In P. Mena, G. Medina, \& R. Hofstede (Eds.), Los páramos del Ecuador. Particularidades, problemas y perspectivas (pp. 161-181). Quito: Ediciones Abya-Yala.

Hofstede, R. (2013). Lo mucho que sabemos del páramo: apuntes sobre el conocimiento actual de la integridad, la transformación y la conservación del páramo. In J. Cortés-Duque \& C. Sarmiento (Eds.), Visión socioecosistémica de los páramos y la alta montaña colombiana: memorias del proceso de definición de criterios para la delimitación de páramos (pp. 252). Bogotá D.C.: Instituto de Investigación de Recursos Biológicos Alexander von Humboldt. 
Hoorn, V., \& Alphen, V. (1994). Salinity control. In H. Ritzema (Ed.),Drainage principles and application (pp. 533-600). Wageningeng, The Netherlands: International Institute for Land Reclamation and Improvement (ILRI).

IDEAM. (2020). Descarga de datos hidrometeorológicos. Retrieved from http://dhime.ideam.gov.co/atencionciudadano/

IGAC. (2003). Estudio general de suelos y zonificación de tierras del departamento de Santander. Retrieved from Bogotá, D.C.:

Jaramillo, D. (2002). Introducción a la ciencia del suelo (1st ed.). Bogotá, D.C.: Universidad Nacional de Colombia.

Josse, C., Cuesta, F., Navarro, G., Barrera, V., Cabrera, E., Chacón-Moreno, E., . . . Tovar, A. (2009). Ecosistemas de los Andes del Norte y Centro. Bolivia, Colombia, Ecuador, Perú y Venezuela. Retrieved from

Juan, P., Mateu, J., Jordan, M. M., Mataix-Solera, J., Meléndez-Pastor, I., \& Navarro-Pedreño, J. (2011). Geostatistical methods to identify and map spatial variations of soil salinity. Journal of Geochemical Exploration, 108 (1), 62-72. doi:10.1016/j.gexplo.2010.10.003

Kirkegaard, J. A., Conyers, M. K., Hunt, J. R., Kirkby, C. A., Watt, M., \& Rebetzke, G. J. (2014). Sense and nonsense in conservation agriculture: Principles, pragmatism and productivity in Australian mixed farming systems. Agriculture, Ecosystems and Environment, 187 , 133-145. doi:10.1016/j.agee.2013.08.011

Lal, R. (1997). Residue management, conservation tillage and soil restoration for mitigating greenhouse effect by CO2-enrichment.Soil and Tillage Research, 43 (1-2), 81-107. doi:10.1016/S0167-1987(97)00036-6

Li, J., Tong, X., Awasthi, M. K., Wu, F., Ha, S., Ma, J., . . He, C. (2018). Dynamics of soil microbial biomass and enzyme activities along a chronosequence of desertified land revegetation. Ecological Engineering, 111 , 22-30. doi:10.1016/j.ecoleng.2017.11.006

López-Bellido, R. J., Fontán, J. M., López-Bellido, F. J., \& López-Bellido, L. (2010). Carbon sequestration by tillage, rotation, and nitrogen fertilization in a mediterranean vertisol. Agronomy Journal, 102 (1), 310-318. doi:10.2134/agronj2009.0165

Löwer, C. (2020). What impact does grazing intensity have on the degradation of vegetation structure in a dry páramo? (Geoecology B.Sc.), University of Bayreuth, Bayreuth, Germany.

Martínez, E., Fuentes, J., \& Acevedo, E. (2008). Carbono orgánico y propiedades del suelo. Revista de la ciencia del suelo y nutrición vegetal, 8 (1), 68-96. doi:10.4067/S0718-27912008000100006

Martinez, G., Vanderlinden, K., Ordóñez, R., \& Muriel, J. L. (2009). Can apparent electrical conductivity improve the spatial characterization of soil organic carbon? Vadose Zone Journal, 8 (3), 586-593. doi:10.2136/vzj2008.0123

Melero, S., López-Bellido, R. J., López-Bellido, L., Muñoz-Romero, V., Moreno, F., \& Murillo, J. M. (2011). Long-term effect of tillage, rotation and nitrogen fertiliser on soil quality in a Mediterranean Vertisol. Soil and Tillage Research, 114 (2), 97-107. doi:10.1016/j.still.2011.04.007

Melero, S., Madejón, E., Ruiz, J. C., \& Herencia, J. F. (2007). Chemical and biochemical properties of a clay soil under dryland agriculture system as affected by organic fertilization. European Journal of Agronomy, 26 (3), 327-334. doi:10.1016/j.eja.2006.11.004

Minaya, V., Corzo, G. A., Solomatine, D. P., \& Mynett, A. E. (2018). Data-driven techniques for modelling the gross primary production of the páramo vegetation using climate data: Application in the Ecuadorian Andean region. Ecological Informatics, 43 , 222-230. doi:10.1016/j.ecoinf.2016.12.002 
Ochoa-Tocachi, B. F., Buytaert, W., Antiporta, J., Acosta, L., Bardales, J. D., Célleri, R., . . De Bièvre, B. (2018). Data Descriptor: High-resolution hydrometeorological data from a network of headwater catchments in the tropical Andes. Scientific Data, 5 , 180080. doi:10.1038/sdata.2018.80

Ochoa-Tocachi, B. F., Buytaert, W., De Bièvre, B., Célleri, R., Crespo, P., Villacís, M., . . Arias, S. (2016). Impacts of land use on the hydrological response of tropical Andean catchments. Hydrological Processes, 30 (22), 4074-4089. doi:10.1002/hyp.10980

Ordoñez, M. C., Galicia, L., Figueroa, A., Bravo, I., \& Peña, M. (2015). Effects of peasant and indigenous soil management practices on the biogeochemical properties and carbon storage services of Andean soils of Colombia. European Journal of Soil Biology, 71 , 28-36. doi:10.1016/j.ejsobi.2015.10.001

Otero, J. D., Figueroa, A., Muñoz, F. A., \& Peña, M. R. (2011). Loss of soil and nutrients by surface runoff in two agro-ecosystems within an Andean paramo area. Ecological Engineering, 37 (12), 2035-2043. doi:10.1016/j.ecoleng.2011.08.001

Patiño, S. (2020). Evaluación del efecto del uso del suelo sobre sus propiedades hidrofísicas en ecosistema de páramo asociadas a los servicios de suministro y regulación hídrica. (Magister en Ingeniería Civil Trabajo de grado de maestría en investigación), Universidad Industrial de Santander, Bucaramanga, Colombia.

Patiño, S., Hernández, Y., Plata, C., Domínguez, I., Daza, M., Oviedo-Ocaña, R., . . Ochoa-Tocachi, B. F. (2021). Influence of land use on hydro-physical soil properties of Andean páramos and its effect on streamflow buffering. Catena, 202 , 105227. doi:https://doi.org/10.1016/j.catena.2021.105227

Peña-Quemba, D., Rubiano-Sanabria, Y., \& Riveros-Iregui, D. (2016). Effects of land use on soil CO2 flux in the Paramo de Guerrero, Colombia. Agronomia Colombiana, 34 (3), 364-373. doi:10.15446/agron.colomb.v34n3.58791

Podwojewski, P., Poulenard, J., Zambrana, T., \& Hofstede, R. (2002). Overgrazing effects on vegetation cover and properties of volcanic ash soil in the páramo of Llangahua and La Esperanza (Tungurahua, Ecuador).Soil Use and Management, 18 (1), 45-55. doi:10.1079/SUM2002100

Poulenard, J., Podwojewski, P., \& Herbillon, A. J. (2003). Characteristics of non-allophanic Andisols with hydric properties from the Ecuadorian páramos. Geoderma, 117 (3-4), 267-281. doi:10.1016/S00167061(03)00128-9

Poulenard, J., Podwojewski, P., Janeau, J. L., \& Collinet, J. (2001). Runoff and soil erosion under rainfall simulation of Andisols from the Ecuadorian Páramo: Effect of tillage and burning. Catena, 45 (3), 185-207. doi:10.1016/S0341-8162(01)00148-5

Quichimbo, P., Tenorio, G., Borja, P., Cárdenas, I., Crespo, P., \& Célleri, R. (2012). Efectos sobre las propiedades físicas y químicas de los suelos por el cambio de la cobertura vegetal y uso del suelo: páramo de Quimsacocha al sur del Ecuador. Suelos Ecuatoriales, 42 (2), 138-153.

Rangel, O. (2000). La región paramuna y franja aledaña en Colombia. In O. Rangel (Ed.), Colombia diversidad biotica III. La región de vida paramuna (pp. 1-23). Bogotá D.C.: Unibiblos.

Sainju, U. M., Whitehead, W. F., \& Singh, B. P. (2003). Agricultural management practices to sustain crop yields and improve soil and environmental qualities. TheScientific WorldJournal, 3 , 768-789. doi:10.1100/tsw.2003.62

Salamanca, S. (1986). La vegetación del páramo, única en el mundo, Colombia, sus gentes y regiones . Retrieved from

Sandoval, M. (2004). Agricultural and settlement frontiers in the tropical Andes : the paramo belt of northern Ecuador, 1960-1990. Mountain Research and Development, 25 (4), 386-387.

Sarmiento, C., \& Ungar, P. (2014). Aportes a la delimitación del páramo mediante la identificación de los límites inferiores del ecosistema a escala 1:25.000 y análisis del sistema social asociado al territorio: 
Complejo de Páramos Jurisdicciones - Santurbán - Berlín departamentos de Santander . Retrieved from Bogotá, D.C.:

Sarmiento, L. (2000). Water balance and soil loss under long fallow agriculture in the Venezuelan Andes. Mountain Research and Development, 20 (3), 246-253. doi:10.1659/02764741(2000)020[0246:WBASLU]2.0.CO;2

Six, J., Frey, S. D., Thiet, R. K., \& Batten, K. M. (2006). Bacterial and fungal contributions to carbon sequestration in agroecosystems.Soil Science Society of America Journal, 70 (2), 555-569. doi:10.2136/sssaj2004.0347

Strudley, M. W., Green, T. R., \& Ascough Ii, J. C. (2008). Tillage effects on soil hydraulic properties in space and time: State of the science. Soil and Tillage Research, 99 (1), 4-48. doi:10.1016/j.still.2008.01.007

Tovar, C., Arnillas, C. A., Cuesta, F., \& Buytaert, W. (2013). Diverging Responses of Tropical Andean Biomes under Future Climate Conditions. PLoS ONE, 8 (5), e63634. doi:10.1371/journal.pone.0063634

USDA. (2011). Electrical Coductivity Test (pp. 1). Washington, D.C.: United States Department of Agriculture (USDA).

USDA, \& NRCS. (2014). Claves para la Taxonomía de Suelos (12th ed.): Departamento de Agricultura de los Estados Unidos (USDA); Servicio de Conservación de Recursos Naturales (NRCS).

Wei, Y. c., Bai, Y. l., Jin, J. y., Zhang, F., Zhang, L. p., \& Liu, X. q. (2009). Spatial Variability of Soil Chemical Properties in the Reclaiming Marine Foreland to Yellow Sea of China. Agricultural Sciences in China, 8 (9), 1103-1111. doi:10.1016/S1671-2927(08)60318-1

WWF. (2006). High Andean wetlands: fragile, strategic ecosystems for millions of people. Retrieved from http://wwf.panda.org/?63460/High-Andean-Wetlands-Regional-Strategy

\section{FIGURE LEGENDS}

Figure 1. Multiannual monthly rainfall in the Berlin meteorological station for the period 1973-2018.

Notes. Dark gray columns () represent wet seasons; light gray columns () represent dry seasons; whiskers (?) show the standard deviation in the multiannual data. Data have been obtained from IDEAM (2020).

Figure 2. Location of sampling units in the study area.

Figure 3. Soil organic matter according to sampling unit and depth.

Note. Ls: paramo grasslands - low slope; Ss: paramo grasslands - steep slope; Ds: paramo - dense shrublands; F: fallow; Oc: onion crops; Pc: potato crops; [?]: median; -: average; ior: outlier; medians with different letters $(a, b, c)$ are statistically different $(=0.05 ;$ Fisher LSD). The dark grey dashed lines (-) show the mean of the six SUs for each depth.

Figure 4. Bulk density according to sampling unit and depth.

Note. Ls: páramo grasslands - low slope; Ss: páramo grasslands - steep slope; Ds: páramo - dense shrublands; F: fallow; Oc: onion crops; Pc: potato crops; [?]: median; -: average; ior: outlier; medians with different letters $(a, b, c)$ are statistically different $(=0.05 ;$ Fisher LSD). The dark grey dashed lines $(-)$ show the mean of the six SUs for each depth.

Figure 5. pH of soil according to sampling unit and depth.

Note. Ls: páramo grasslands - low slope; Ss: páramo grasslands - steep slope; Ds: páramo - dense shrublands; F: fallow; Oc: onion crops; Pc: potato crops; [?]: median; -: average; ior: outlier; medians with different letters 
$(a, b, c)$ are statistically different (=0.05; Fisher LSD). The dark grey dashed lines (-) show the mean of the six SUs for each depth.

Figure 6. Electrical conductivity of the soil according to sampling unit and depth.

Note. Ls: páramo grasslands - low slope; Ss: páramo grasslands - steep slope; Ds: páramo - dense shrublands; F: fallow; Oc: onion crops; Pc: potato crops; [?]: median; -: average; ior: outlier; medians with different letters $(a, b, c)$ are statistically different $(=0.05$; Fisher LSD). The dark grey dashed lines $(-)$ show the mean of the six SUs for each depth.

\section{Hosted file}

HYP-21-0580-Table1.docx available at https://authorea.com/users/426976/articles/531313effects-of-agriculture-and-seasonality-on-the-soil-hydrophysical-properties-of-highandean-dry-p\%C3\%A1ramo-grasslands

\section{Hosted file}

HYP-21-0580-Table2.docx available at https://authorea.com/users/426976/articles/531313effects-of-agriculture-and-seasonality-on-the-soil-hydrophysical-properties-of-highandean-dry-p\%C3\%A1ramo-grasslands

\section{Hosted file}

HYP-21-0580-Table3.docx available at https://authorea.com/users/426976/articles/531313effects-of-agriculture-and-seasonality-on-the-soil-hydrophysical-properties-of-highandean-dry-p\%C3\%A1ramo-grasslands

\section{Hosted file}

HYP-21-0580-Table4.docx available at https://authorea.com/users/426976/articles/531313effects-of-agriculture-and-seasonality-on-the-soil-hydrophysical-properties-of-highandean-dry-p\%C3\%A1ramo-grasslands 


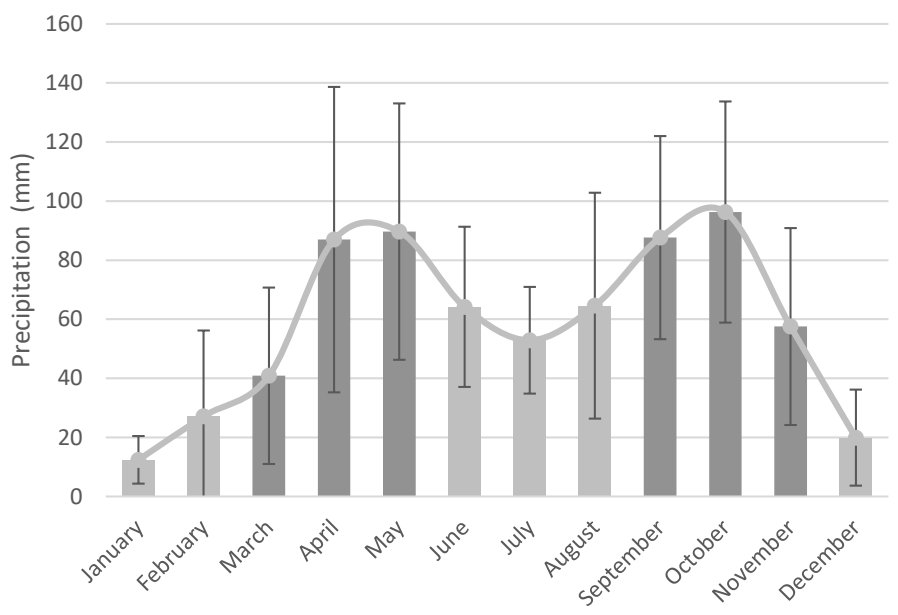



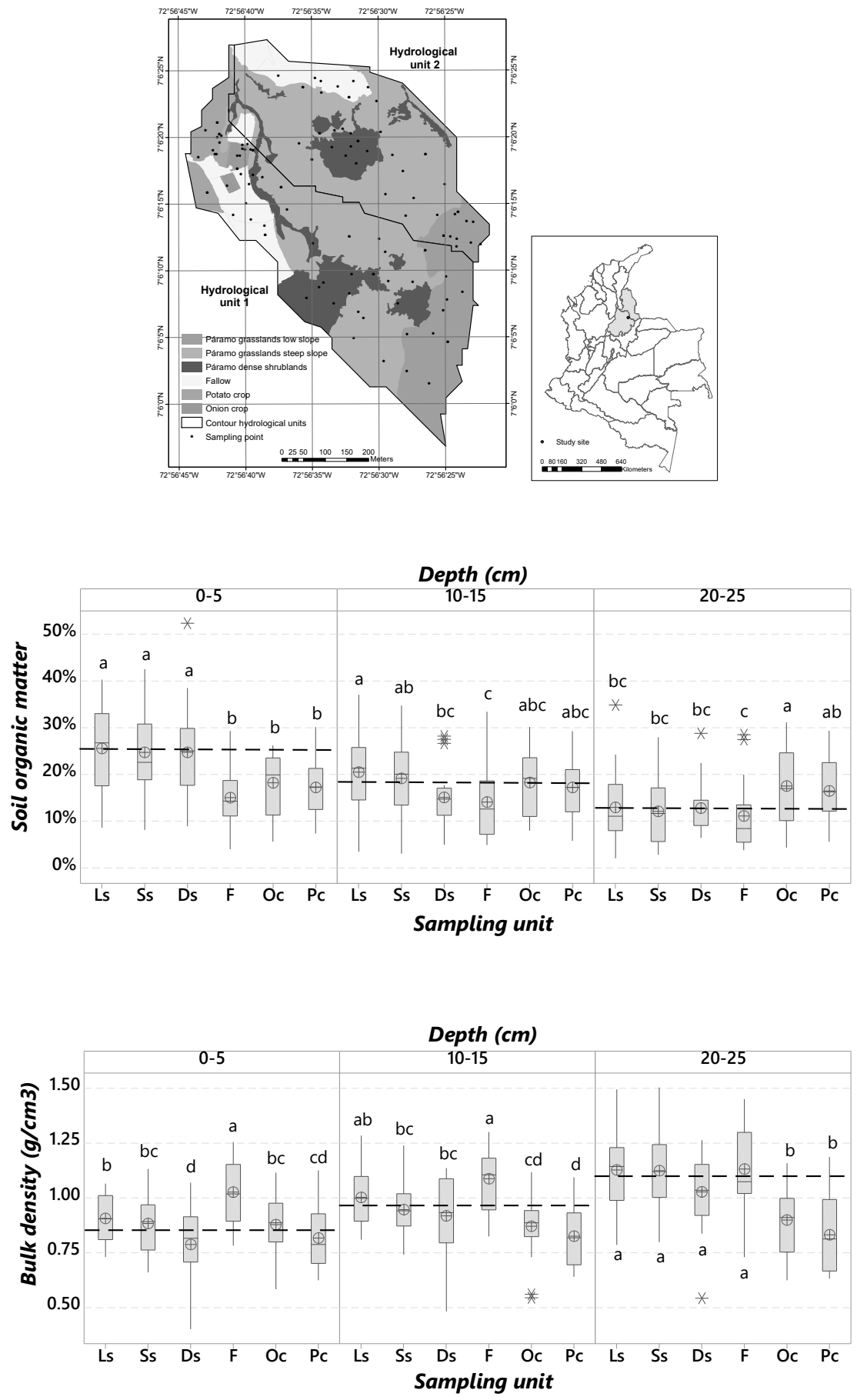

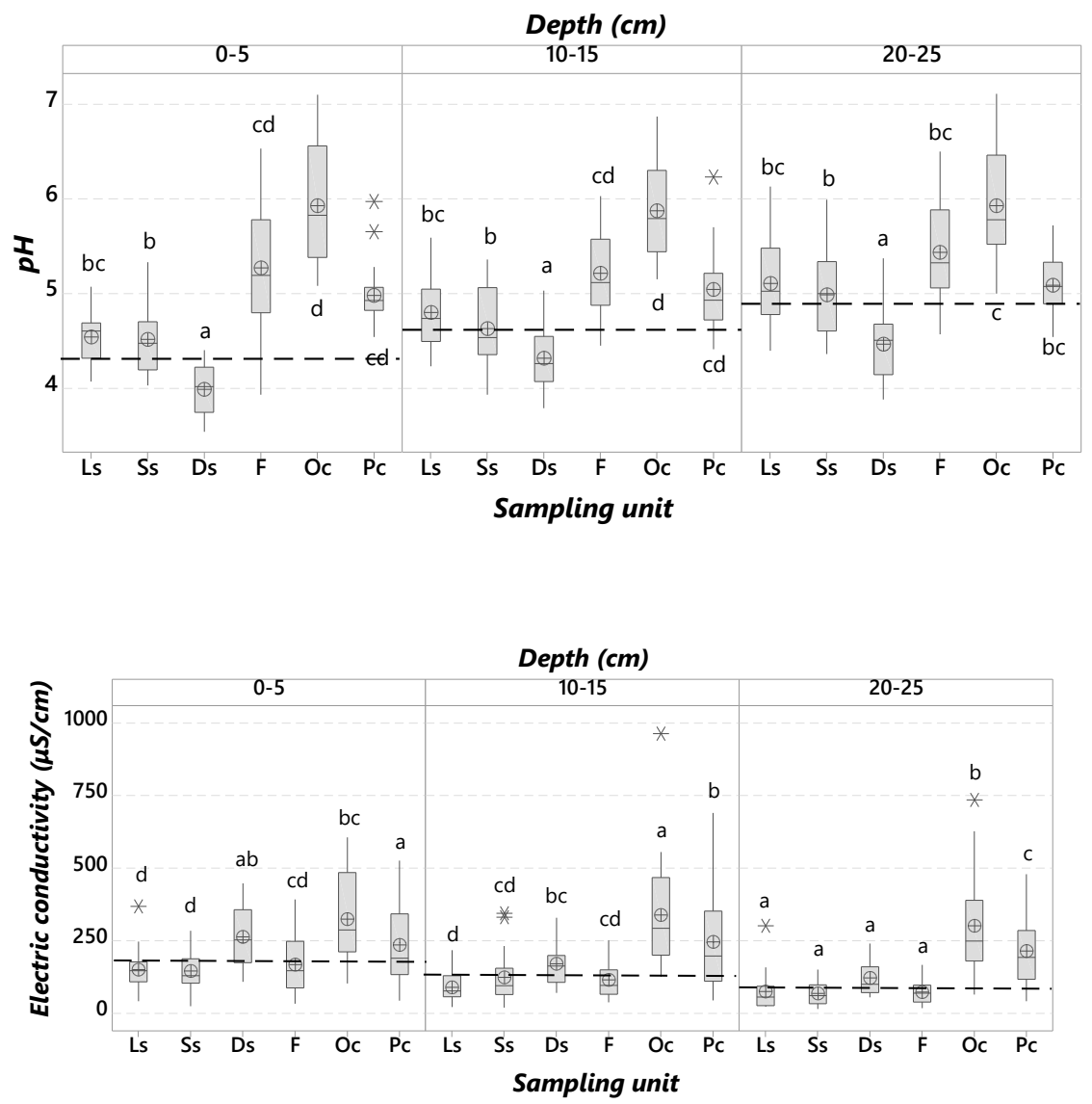